\title{
PENINGKATAN KUALITAS ZIRKONIA HASIL OLAH PASIR ZIRKON
}

\author{
Dwiretnani Sudjoko, Triyono \\ Pusat Teknologi Akselerator dan Proses Bahan - BATAN Yogyakarta55281
}

\begin{abstract}
ABSTRAK
PENINGKATAN KUALITAS ZIRKONIA HASIL OLAH PASIR ZIRKON. Penelitian ini dilakukan untuk mempelajari peningkatan kualitas zirkonia yang diperoleh dari hasil olah pasir zirkon dengan jalan peningkatan tingkat pelindian air, salah satu tahapan pada proses pengolahan pasir zirkon, dan variasi konsentrasi ammonium hidroksida yang digunakan pada pengolahan pasir zirkon. Proses dilakukan sesuai jalur proses peleburan alkali - pelindian dengan air - pelindian dengan asam klorida - pengendapan - kalsinasi. Dari hasil penelitian ini didapatkan hasil, makin tinggi tingkat pelindian air kandungan zirkonia hasil makin bertambah besar, tetapi untuk variasi konsentrasi ammonium hidroksida ternyata makin tinggi konsentrasi ammonium hidroksida kandungan zirkonia makin berkurang. Kondisi optimum diperoleh pada tingkat pelindian air tingkat ketiga dan konsentrasi ammonium hidroksida 12,5\%. Pada kondisi ini kandungan zirkonia sebesar 99,01\%.
\end{abstract}

\section{ABSTRACT}

QUALITY INCREASING OF ZIRCONIA FROM TREATMENT OF ZIRCON SAND. This research is intended to study of quality increasing of zirconia from treatment of zircon sand, by increasing of stage in water leaching, one stage in treatment process of zircon sand. The processis undertaken with the approach of alkaline fusion - water leaching, hydrochloric acid leaching - precipitation - calcination. From this research, it was obtained that increasing in stage of water leaching was caused the concentration of zirconia increase, but when increasing in concentration of ammonium hydroxide, the concentration of zirconia was decreased. The optimum condition is the third stage in leaching and the optimum concentration of ammonium hydroxide was $12,5 \%$. In this condition, the final result obtained was zirconia with the purity around $99,01 \%$.

\section{PENDAHULUAN}

$\mathrm{M}$

akin berkembangnya penggunaan zirkonia sekarang ini, membutuhkan pengembangan yang tepat untuk pengambilan zirkonia dari mineralnya, sehingga diperlukan usaha untuk meningkatkan kualitas zirkonia. Penyiapan zirkonia dari pasir zirkon melalui beberapa tahapan proses, sehingga tiap tahapan perlu perlu lebih dicermati untuk dapat meningkatkan hasil zirkonia. Penelitian pembuatan zirkonia makin maju, hal ini disebabkan bahan zirkonia memiliki beberapa keunggulan sehingga dapat digunakan untuk berbagai keperluan, misalnya komponen otomotif, elektronik, sensor oksigen dan elektrolit padat dalam sel bahan bakar. Dengan berkembangnya teknologi, maka pengembangan penggunaan zirkonia makin bertambah misalnya dalam keramik yang memakai unsur zirkonium menunjukkan kearah pengembangan keramik berbasis zirkonia ${ }^{(2)}$. Zirkonia juga, merupakan bahan baku pembuatan $\mathrm{ZrO}_{2}$ dengan kestabilan parsial yang banyak digunakan dalam industri, misalnya industri pembuatan krus, untuk peleburan logam campuran dan logam muliadan industri lain yang bekerja pada suhu tinggi

Di Indonesia sumber mineral zirkon selain diperoleh dari Bangka, juga dapat diperoleh dari Kalimantan. Mineral zirkon akan mempunyai prospek cerah sebagai sumber utama zirkonia, jika bahan tersebut dapat diproses secara tepat.

Salah satu tahapan proses dalam unit pengolahanpasir zirkon adalah pengambilan zirkon dari pasir zirkon. Pasir zirkon dilebur dengan soda api, hasil leburan dilindi lebih dahulu dengan air, kemudian residu yang diperoleh dilindi dengan asam klorida. Pelindian adalah proses pengambilan solute dari padatan dengan menggunakan pelarut. Proses ini selalu terjadi dalam dua tahapan, yaitu kontak antara padatan dan pelarut yang berakibat terjadinya perpindahan massa dari padatan kelarutan dan pemisahan padatan dan larutan setelah proses selesai. Pada penelitian ini, akan dicoba untuk meningkatkan kualitas hasil zirkonia dengan jalan 
meningkatkan tingkat pelindian air. Pelindian dengan air dilakukan secara catu di dalam gelas beker yang dilengkapi dengan pengaduk, dilanjutkan pelindian dengan $\mathrm{HCl}$ dan kalsinasi. Pada dasarnya proses ini adalah untuk melepaskan komponen $\mathrm{SiO}_{2}$. Komponen $\mathrm{SiO}_{2}$ dalam mineral zirkon membentuk ikatan yang sangat kuat sehingga tidak dapat dipisahkan secara fisik maupun dengan pelarutan. Dengan menggunakan soda api dan proses pada suhu yang tinggi, maka ikatan $\mathrm{SiO}_{2}$ dapat lepas dari mineral zirkon dan berikatan dengan soda api. Dengan terlepasnya ikatan tersebut maka diperoleh suatu senyawa yang akan lebih mudah untuk dilarutkan.

Reaksi yang terjadi pada proses peleburan ${ }^{[1,2,3,4]}$ adalah

$$
\mathrm{ZrSiO}_{4}+4 \mathrm{NaOH} \rightarrow \mathrm{Na}_{2} \mathrm{ZrO}_{3}+\mathrm{Na}_{2} \mathrm{SiO}_{3}+2 \mathrm{H}_{2} \mathrm{O}
$$

Natrium silikat larut dalam air,sedangkan natrium zirkonat tidak larut dalam air, sehingga dengan pelindian air silikat akan terpisah. Pada penelitian yang terdahulu ${ }^{(5)}$, pelindian dengan air hanya dilakukan dengan satu tingkat pelindian, sehingga kemungkinan ada sebagian sisa natrium silikat yang belum terambil juga sebagian dari sisa soda api yang belum bereaksi, yang masih menempel pada residu hasil pelindian dengan air, sehingga pada penelitian ini dicoba menggunakan tiga tingkat pelindian air. Residu hasil pelindian air ini kemudian dikeringkan dan dilindi dengan asam klorida dengan perbandingan tertentu untuk mengambil unsur zirkon, filtrat yang didapat mengandung zirkon, diendapkan dengan ammonium hidroksida, endapan yang diperoleh dikeringkan dan dikalsinasi maka akan diperoleh zirkonia.

Pada penelitian ini variabel yang akan diteliti adalah tingkat pelindian air dan pengaruh konsentrasi ammonium hidroksida

\section{TATA KERJA}

\section{Bahan :}

Pasir zirkon dari Bangka, $\mathrm{Na} \mathrm{OH}$ teknis, asam klorida 37\% dari Aldrich, amonium hidroksida dari Aldrich, air suling dan bahan untuk preparasi analisis.

\section{Cara kerja :}

Pada penelitian ini ada beberapa tahapan proses yang dilakukan

1. Proses peleburan dengan soda api dilakukan pada suhu $700{ }^{\circ} \mathrm{C}$, waktu 3 jam dengan perbandingan berat soda api : berat pasir zirkon sebesar 1,1:1 didalam tangki peleburan. Setelah peleburan selesai, hasil leburan diambil dan kemudian dilindi dengan air.

2. Pelindian dengan air, pada penelitian ini akan dilakukan sebanyak tiga kali. Tiap kali pelindian digunakan air suling sebanyak $300 \mathrm{ml}$ untuk setiap $10 \mathrm{~g}$ hasil leburan. Pelindian dilakukan dengan memasukkan hasil leburan dalam tangki berpengaduk dari gelas dengan kecepatan pengadukan sebesar $180 \mathrm{rpm}$, waktu 1 jam. Residu hasil pelindian tingkat pertama, kedua, ketiga, dilindi dengan kondisi operasi yang sama. Residu hasil pelindian dari tiap-tiap tingkat dikeringkan, kemudian dilindi dengan $\mathrm{HCl}$.

3. Pelindian $\mathrm{HCl}$ dilakukan dengan cara dan alat yang sama dengan pelindian dengan air. Kondisi operasi yang digunakan adalah $\mathrm{HCl} \mathrm{10 \%} \mathrm{sebanyak} 300 \mathrm{ml}$ untuk tiap $10 \mathrm{~g}$ residu hasil pelindian dengan air, kecepatan pengaduk $180 \mathrm{rpm}$ dan waktu 1 jam. Hasil pelindian dipisahkan dengan penyaringan, filtrat yang diperoleh kemudian diendapkan dengan amonium hidroksida.

4. $\quad$ Endapan yang diperoleh kemudian dipisahkan dari larutannya, kemudian dikalsinasi

5. 5.Kalsinasi dilakukan pada suhu $1000{ }^{\circ} \mathrm{C}$ selama 3 jam. Hasil yang diperoleh kemudian dianalisis dengan XRF dan XRD.

\section{HASIL DAN PEMBAHASAN}

\section{Pengaruh tingkatpelindian dengan air}

Percobaan pelindian dengan air dilakukan pada suhu kamar hasilnya dapat dilihat pada Tabel 1 dan 2 , sedangkan pengaruh konsentrasi amonium hidroksida yang digunakan pada pembuatan endapan $\mathrm{Zr}(\mathrm{OH})_{4}$ terhadap hasil $\mathrm{ZrO}_{2}$ dapat dilihat pada Tabel 3 . 
Tabel 1. Pelindian hasil leburan dengan air ( suhu kamar, kecepatan pengaduk $180 \mathrm{rpm}$, volume air $300 \mathrm{ml}$ untuk tiap $10 \mathrm{~g}$ hasil leburan)

\begin{tabular}{|c|c|c|}
\hline Tingkat Pelindian air & Kadar Zr dalam residu pelindian air , \% & $\mathrm{pH}$ filtrat hasil pelindian air \\
\hline \hline I & 38,41 & 10,22 \\
\hline II & 50,90 & 11,48 \\
\hline III & 54,59 & 12,64 \\
\hline
\end{tabular}

Residu hasil pelindian dengan air yang diperoleh kemudian dikeringkan, dan dilindi dengan $\mathrm{HCl} 10 \%$. Dari Tabel 1 dapat dilihat bahwa makin bertambah tingkat pelindian air kandungan $\mathrm{Zr}$ dalam residu pelindian air makin bertambah besar, karena senyawa lain yang larut kedalam air yang bisa menjadi pengotor makin bertambah banyak, sehingga kandungan zirkon dalam residu hasil pelindian air makin bertambah. Pada pemrosesan selanjutnya didapatkan hasil akhir $\mathrm{ZO}_{2}$ dengan kandungan yang makin bertambah besar seperti terlihat dalam Tabel 2. Hasil kalsinasi dari pelindian tingkat 2 ketingkat 3 kenaikan kandungan $\mathrm{ZrO}_{2}$ tidak sebesar kenaikan dari tingkat 1 ke tingkat 2, sehingga optimum tingkat pelindian air diambil pada tingkat 3 . Apalagi pada kondisi ini kandungan zirkonia yang didapat sudah cukup tinggi sekitar $99,01 \%$.

Tabel 2. Pengaruh tingkat pelindian air terhadap pelindian $\mathrm{HCl}$ dan hasil $\mathrm{ZrO}_{2}$ (kecepatan pengaduk $180 \mathrm{rpm}$, suhu kamar, volume $\mathrm{HCl} 10 \%$ sebesar $300 \mathrm{ml}$ untuk tiap $10 \mathrm{~g}$ residu pelindian air)

\begin{tabular}{|c|c|c|c|c|}
\hline Tingkat Pelindian air & $\begin{array}{c}\text { Kandungan } \mathrm{Zr} \text { dalam } \\
\text { residu pelindian } \mathrm{HCl}, \%\end{array}$ & $\begin{array}{c}\mathrm{pH} \text { filtrat hasil } \\
\text { pelindian } \mathrm{HCl}\end{array}$ & $\begin{array}{c}\text { Kandungan } \mathrm{Zr} \\
\text { dalam } \mathrm{ZrO}_{2} \text { hasil, \% }\end{array}$ & $\begin{array}{c}\text { Kandungan } \mathrm{ZrO}_{2} \\
\text { dalam } \mathrm{ZrO}_{2} \text { hasil, \% }\end{array}$ \\
\hline \hline I & 22,90 & 1,90 & 39,03 & 52,72 \\
\hline II & 24,68 & 0,44 & 69,22 & 93,50 \\
\hline III & 25,18 & 0,44 & 73,30 & 99,01 \\
\hline
\end{tabular}

\section{Pengaruh konsentrasi ammonium hidroksida}

Untuk mengetahui pengaruh konsentrasi ammonium hidroksida yang digunakan dalam pembuatan endapan $\mathrm{Zr}(\mathrm{OH})_{4}$ dilakukan hanya dengan menggunakan amonium hidroksida tanpa pengenceran langsung $(25 \%)$, konsentrasi $20 \%$ dan dengan pengenceran dua kali. Untuk amonium hidroksida dengan pengenceran yang lebih besar ternyata hasil endapannya terlalu sedikit, sehingga tidak dapat dibandingkan dengan ketiga kondisi di atas. Pada penelitian ini pelindian dengan $\mathrm{HCl}$ hanya dilakukan satu tingkat, supaya filtrat yang diperoleh konsentrasinya tidak terlalu encer. Pada Tabel 3 diberikan hasil-hasil penelitian dengan variasi konsentrasi ammonium hidroksida.

Dari Tabel 3 dapat dilihat bahwa makin tinggi konsentrasi ammonium hidroksida yang digunakan, diperoleh hasil akhir zirkonia dengan kandungan $\mathrm{ZrO}_{2}$ yang yang lebih rendah. Hal ini kemungkinan karena pengaruh $\mathrm{pH}$, untuk pengendapan $\mathrm{Zr}(\mathrm{OH})_{4}$ diperlukan $\mathrm{pH}$ sekitar $10^{[6]}$

Tabel 3. Pengaruh konsentrasi ammonium hidroksida terhadap hasil zirkonia (kecepatan pengaduk $180 \mathrm{rpm}$, suhu kamar,volume zirkon klorida yang digunakan $50 \mathrm{ml}$ )

\begin{tabular}{|c|c|c|}
\hline Konsentrasi ammonium, hidroksida, $\%$ & pH pengendapan & Kandungan $\mathrm{ZrO}_{2}$ dalam hasil kalsinasi, $\%$ \\
\hline \hline $25 \%$ & 11,2 & 69,87 \\
\hline $20 \%$ & 10,9 & 71,36 \\
\hline $12,5 \%$ & 10,05 & 99,01 \\
\hline
\end{tabular}

Selanjutnya kristal $\mathrm{ZrO}_{2}$ yang diperoleh dari hasil penelitian di atas dianalisis struktur kristalnya menggunakan alat XRD dan hasilnya tertera pada Gambar 1. Dari gambar ini dapat dilihat pola difraksi pasir zirkon, pada Gambar 1.1 pola difraksi hasil analisis penelitian dengan variabel tingkat pelindian air suhu kalsinasi $1000^{\circ} \mathrm{C}$, waktu kalsinasi 3 jam, dapat dilihat pada Gambar 1.2 untuk tingkat pelindian air tingkat 1 , Gambar 1.3 untuk tingkat pelindian air 2 dan Gambar 1.4 untuk tingkat pelindian air 3. Sumbu $Y$ menyatakan intensitas yang tercatat dalam cacah perdetik. Intensitas menyatakan banyaknya hamburan yang masuk ke 
pencatat detektor yang dicacah tiap detik. Sumbu $\mathrm{X}$ menyatakan sudut hamburan $2 \theta$ yang merupakan sudut pergerakan detektor.

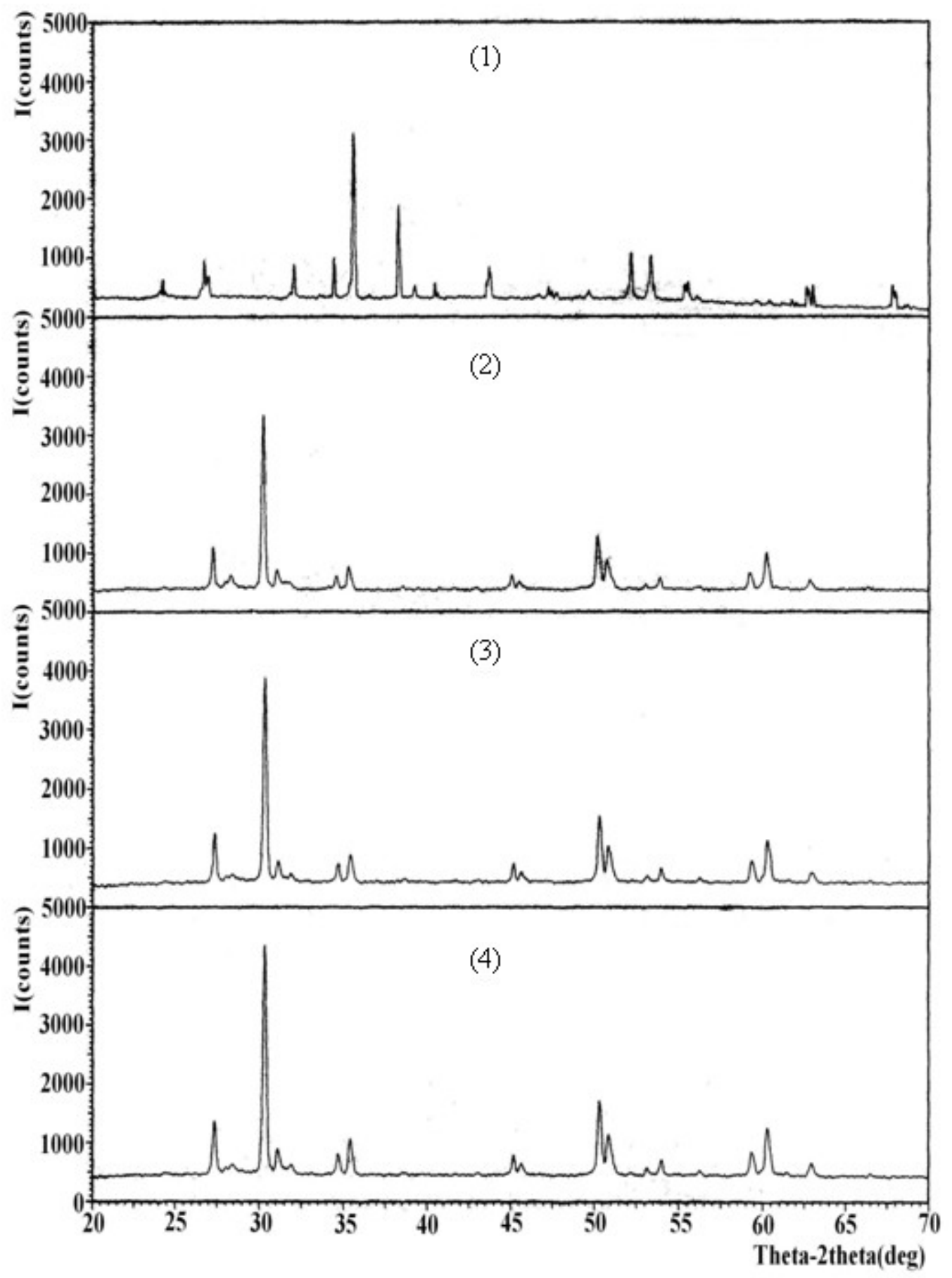

Gambar 1. Pola difraksi hasil analisis dengan XRD pada sampel pasir zirkon

$\mathrm{ZrO}_{2}$ hasil pelindian air tingkat $1 \mathrm{ZrO}_{2}$ hasil pelindian air tingkat $2 \mathrm{ZrO}_{2}$ hasil pelindian air tingkat 3

Pada Gambar1.1, pola difraksi dari pasir zirkon, muncul beberapa puncak sehingga dapat disimpulkan bahwa padatan pasir zirkon berbentuk poli kristal. Pendinginan yang relatif lama sesudah kalsinasi akan menghasilkan bahan berstruktur kristal. Kristal merupakan susunan atom, ion, atau molekul yang teratur dan berulang dalam sistem tiga dimensi. Dari Gambar 1.2, 1.3 dan1.4, puncak-puncak difraksi yang terbentuk dapat dilihat makin bertambah tinggi tingkat pelindian maka intensitasnya juga makin tinggi, karena kemungkinan 
kristal $\mathrm{ZrO}_{2}$ yang terbentuk baru sedikit dan belum sempurna, masih bercampur dengan puncak-puncak yang lain. Puncak $\mathrm{ZrO}_{2}$ kelihatan pada sudut $2 \theta$ sebesar 30,1551 dengan orientasi bidang (111), sudut $2 \theta$ sebesar 50,1747 dengan orientasi bidang (2 20 ), sudut $2 \theta$ sebesar 60,1628 dengan orientasi bidang (2 40 ) dan struktur kristalnya monoklin ${ }^{[6]}$. Puncak-puncak yang muncul pada analisis XRD mempunyai intensitas yang berbedabeda. Peningkatan intensitas ini berkaitan dengan kesempurnaan kristal yang terbentuk, semakin sempurna kristal yang terbentuk, semakin tinggi intensitasnya pada sudut Bragg yang sama (orientasi kristal yang sama) ) $^{[7]}$. Hal ini disebabkan semakin sempurna struktur kristal , maka diffraksi panjang gelombang dengan fase yang berlawanan makin berkurang.

Pada Gambar 1.2, 1.3,1.4, terlihat ada tiga puncak yang berstruktur monoklin dengan intensitas yang berbeda. Intensitas tertinggi diperoleh pada sudut $2 \theta$ sebesar 30,1551 (111). Hal ini menunjukkan bahwa sampel $\mathrm{ZrO}_{2}$ dengan struktur kristal dan orientasi bidang (111) lebih sempurna daripada orientasi (2 20 ) dan (2 4 0). Dari acuan diperoleh hasil bahwa sudut Bragg yang diperoleh sedikit menyimpang dari keadaan yang sebenarnya untuk kristal $\mathrm{ZrO}_{2}$ yaitu untuk struktur dengan orientasi (111) mempunyai sudut hamburan 28,2136. Penyimpangan atau pergeseran sudut hamburan tersebut dapat dijelaskan sebagai berikut, apabila sinar $X$ mengenai permukaan kristal dengan sudut $\theta$, maka kristal akan mendifraksikan sinar $X$ yang panjang gelombangnya sesuai dengan jarak antar kisi. Pola interferensi hasil difraksi akan saling menguatkan apabila panjang gelombang yang terdifraksi adalah sefase ${ }^{[7]}$. Tetapan kisi yang ideal ditentukan oleh kesempurnaan kristal yang terbentuk. Ini menunjukkan bahwa pada suhu kalsinasi proses kristalisasi belum sempurna. Ketidaksempurnaan kristalisasi disebabkan oleh mobilitas dan suhu proses kristalisasi kurang dan penyesuaian orientasi dalam pertumbuhan kristal. Prinsip kerja XRD berdasarkan pada difraksi sinar $\mathrm{X}$ yang merupakan radiasi elektromagnetik. Apabila butiran $\mathrm{ZrO}_{2}$ ditembak dengan sinar $\mathrm{X}$, maka sinar $\mathrm{X}$ tersebut sebagian akan diserap oleh $\mathrm{ZrO}_{2}$ dan sebagian lagi akan dihamburkan, sehingga intensitas sinar yang ditransmisikan akan lebih rendah dari sinar yang datang kearah substrat tersebut. Berkas difraksi terjadi jika ada berkas sinar yang saling menguatkan. Setiap unsur mempunyai karakteristik berkas difraksi yang berbeda, sehingga berkas difraksi tergantung pada bentuk kisi dari unsur yang terkena tembakan sinar X. Berdasarkan pernyataan ini sudut difraksi ditentukan oleh tetapan kisi. Suatu kristal dikatakan tunggal apabila tersusun dari satu macam sistem kristal dalam susunan unit-unit selnya dan bila kristal tersebut dikarakterisasi dengan XRD metoda serbuk, akan dihasilkan difraktogram dengan puncak-puncak yang tajam dan tidak melebar. Dengan membandingkan nilai jarak $\mathrm{d}$, sudut $2 \theta$ dan $1 / \mathrm{l}_{0}$ kristal hasil proses dengan standar terdapat keidentikan nilai. Puncak tajam pada difraktogram kristal hasil proses juga merupakan pendukung bahwa kristal hasil proses tunggal.

Dari Gambar 1 dapat dilihat bahwa intensitas tertinggi pada ketiga orientasi bidang diperoleh pada kristal hasil pelindian air tingkat 3 , makin tinggi intensitas kristalinitas makin tinggi.

\section{KESIMPULAN}

Dari hasil penelitian ini dapat ditarik kesimpulan bahwa kondisi optimum untuk tingkat pelindian air dapat diperoleh pada tingkat 3, sedangkan konsentrasi ammonium hidroksida yang optimum diperoleh pada konsentrasi sebesar 12,5\%. Pada kondisi ini $\mathrm{ZrO}_{2}$ yang diperoleh berwarna putih dan mempunyai kandungan $\mathrm{ZrO}_{2}$ sebesar 99,01\%. Dibandingkan dengan proses sebelumnya, menggunakan pelindian air 1 tingkat, zirkonia yang diperoleh mempunyai kandungan zirkonia sebesar $52,72 \%$, sedangkan pada penelitian ini, pelindian air 3 tingkat, menghasilkan zirkonia dengan kandungan zirkonia sebesar $99,01 \%$, sehingga peningkatan kualitas hasil yang diperoleh cukup besar. Kristal zirkonia yang terjadi berstruktur monoklin dengan sudut orientasi $\left(\begin{array}{lll}1 & 1 & 1\end{array}\right)$, mempunyai intensitas yang lebih tinggi dibandingkan dengan sudut orientasi (2 2 0) maupun (2 4 0), sehingga kristalnya lebih sempurna.

\section{UCAPAN TERIMAKASIH}

Penulis mengucapkan terimakasih yang sebesar-besarnya kepada Sdr. Mujiman yang telah membantu terlaksananya penelitian ini sampai selesai, juga kepada teknisi dari bagian analisis yang telah membantu menganalisis hasil penelitian ini. 


\section{DAFTAR PUSTAKA}

1. LUSTMAN,B dan KERZE,F, The Metallurgy of Zirconium, first edition, Mc Graw Hill Book Company, New York (1955).

2. http://www.chemlink.com.aul zirkon.htm.

3. ELINSON,S.V.dan PETROV,K.L., Zirconium, Chemical and Physical Method of Analysis, AEC-tr-5373 (1960).

4. JACOBSON,C.A., Encyclopedia of chemical Reaction, Reinhold Publishing Corporation, New York (1948).

5. DWIRETNANI SUDJOKO, MUZAKKY, Pengambilan Silikat dari Hasil Peleburan Pasir Zirkon Dengan Pelindian Memakai Air, ProsidingPPI PPBMIBatan, Yogyakarta (1985).

6. www.scienedirect.com, V.A.TARNOPOLSKY, et.al., Influence of thermal treatment on the ion transport propeties of hydrated zirconia

7. BONDAR, B.et al, Journal Material Science ( 1995)

8. WILLARD,H.H. et al, Instrumental Method of Analysis, D.V. Nostrand Co, (1974) 